\title{
Genome-wide association study for milking speed in French Holstein cows
}

\author{
Andrew Marete, ${ }^{*} \dagger^{1}$ Goutam Sahana, $\dagger$ Sébastien Fritz, ${ }^{*} \ddagger$ Rachel Lefebvre, ${ }^{*}$ Anne Barbat, ${ }^{*}$ \\ Mogens Sandø Lund, † Bernt Guldbrandtsen, $†$ and Didier Boichard* \\ *INRA, UMR 1313 GABI, AgroParisTech, Université Paris-Saclay, 78350 Jouy-en-Josas, France \\ †Aarhus University, Center for Quantitative Genetics and Genomics, 8830 Tjele, Denmark \\ $\ddagger A L L I C E, 75595$ Paris, France
}

\section{ABSTRACT}

Using a combination of data from the BovineSNP50 BeadChip SNP array (Illumina, San Diego, CA) and a EuroGenomics (Amsterdam, the Netherlands) custom single nucleotide polymorphism (SNP) chip with SNP pre-selected from whole genome sequence data, we carried out an association study of milking speed in 32,491 French Holstein dairy cows. Milking speed was measured by a score given by the farmer. Phenotypes were yield deviations as obtained from the French evaluation system. They were analyzed with a linear mixed model for association studies. We identified SNP on 22 chromosomes significantly associated with milking speed. As clinical mastitis and somatic cell score have an unfavorable genetic correlation with milking speed, we tested whether the most significant SNP on these 22 chromosomes associated with milking speed were also associated with clinical mastitis or somatic cell score. Nine hundred seventy-one genome-wide significant SNP were associated with milking speed. Of these, 86 were associated with clinical mastitis and 198 with somatic cell score. The most significant association signals for milking speed were observed on chromosomes $7,8,10$, 14 , and 18. The most significant signal was located on chromosome 14 (ZFAT gene). Eleven novel milking speed quantitative trait loci (QTL) were observed on chromosomes 7, 10, 11, 14, 18, 25, and 26. Twelve candidate SNP for milking speed mapped directly within genes. Of these, 10 were QTL lead SNP, which mapped within the genes HMHA1, POLR2E, GNB5, KLHL29, ZFAT, KCNB2, CEACAM18, CCL24, and LHPP. Limited pleiotropy was observed between milking speed QTL and clinical mastitis.

Key words: milking speed, mastitis, bovine, genomewide association study, pleiotropy

\footnotetext{
Received October 30, 2017.

Accepted March 16, 2018.

${ }^{1}$ Corresponding author: andrew.marete@inra.fr
}

\section{INTRODUCTION}

Milking speed (MS) measured as the time taken to milk a cow potentially affects the labor cost per cow. Different devices integrated into milking machines [e.g., LactoCorder (Hoefelmayr and Faerber WMB AG, Balgach, Switzerland, 2007), Bou-Matic (Bou-Matic, Madison, WI), or voluntary milking systems (Davis et al., 2008)] provide objective measures of MS, such as average and maximum milk flow rate, and total milking time. Alternatively, MS can be subjectively scored by the farmer. This system is quite reliable in small- to medium-size herds because of the repeated daily milking work. In France, MS is measured subjectively (Rupp and Boichard, 1999) for genetic evaluation purposes.

The relationship between MS with clinical mastitis (CM) and SCS is complex. A previous study in French Holstein reported positive genetic correlations between MS and CM (0.18) and between CM and SCS (0.70; Govignon-Gion et al., 2016). Similarly, a positive genetic correlation between MS and SCC was reported by several authors [0.44 (Rupp and Boichard, 1999), 0.60 (Gäde et al., 2007), and 0.46 (Samoré et al., 2010)], indicating the existence of an unfavorable relationship between MS and mastitis. Genetic correlation between MS and SCS was similar over 2 lactations, with an average correlation of 0.62 (Boettcher et al., 1998). These results support an association between MS and CM. This relationship is plausible because both traits are affected by the anatomy of the teat canal. Animals with a wider teat canal and sphincter on average show a higher milk flow, but the main disadvantage is that teat canals with a greater diameter simultaneously facilitate access to pathogens (Gäde et al., 2007; Sewalem et al., 2011). Another mechanism explaining this positive correlation is that fast milking extracts more alveolar milk rich in somatic cells (Ferneborg and Svennersten-Sjaunja, 2015). But fast milking cows have a complete flush of milk along with bacteria, which may contribute to preventing CM. Slow milking could lead to increased mastitis incidence due to incomplete 
milk-out, or irritated teat ends because of extended milking time (Dodd and Neave, 1951). Milking speed, therefore, should not be too fast or too slow, as both instances would probably lead to an increased incidence of CM; rather, MS should be at an intermediate optimum (Wiggans et al., 2007).

Heritability of MS is moderate: $\mathrm{h}^{2}=0.17$ for $305-\mathrm{d}$ farmer scores in French Holstein (Rupp and Boichard, 1999) and 0.14 in Canadian Holstein (Sewalem et al., 2011). It is higher for measured milking time (e.g., 0.38 in German Holstein; Gäde et al., 2007). These values are moderate and high enough for genetic selection to be effective. Nevertheless, little selection has been done on MS due to potential detrimental consequences on mastitis. Mastitis has negative financial effects on the farmer and biological effects on the cow. Financial effects include milk price penalty for high cell counts, treatment cost, loss of milk sales (due to CM and treatment), loss of production over the rest of the lactation, and increased risk of culling. Biological effects on the cow include udder injury and incomplete udder draining, which contribute negatively to cows' welfare. In the breeding objective, it would be desirable to improve MS without increasing mastitis. The QTL with effects not in line with the genetic correlation (i.e., improving MS without affecting mastitis) would be especially useful to reach this objective. In this study, we report on a genome-wide association study (GWAS) for MS, test the SNP associated with MS for associations with CM and SCS, and explore novel MS QTL and candidate genes associated with MS in French Holstein cattle.

\section{MATERIALS AND METHODS}

\section{Study Population}

A total of 32,491 cows with all phenotypes (MS, SCS, and $\mathrm{CM}$ ) and genotypes were included in this study. Milking speed score $(1=$ slow to $5=$ fast $)$ is a subjective appraisal given by the farmer and recorded by the type classifier during classification visit. There was only one score for each cow, obtained in the first half of the first lactation. Somatic cell counts were obtained at each monthly test-day. Somatic cell score was defined in the usual way as SCS $=3+\log _{2}(\mathrm{SCC} / 100,000)$ and averaged over the lactation. The $\mathrm{CM}$ events were declared by the farmer and recorded by the technician at each test-day. The phenotype was recorded as one if the cow had at least one CM incidence in the lactation and zero otherwise. Yield deviations (YD, VanRaden and Wiggans, 1991), that is, performances adjusted for nongenetic effect, were obtained from the French national evaluation system (Boichard et al., 2012b). As SCS and
CM might have repeated records, YD was an average over the lactations. Finally, each cow received one phenotype for each trait. Technically, the phenotypes corresponding to MS, SCS, and CM are trait deviations, and not YD (as would be for milk production traits); however, to conform with the original terminology by VanRaden and Wiggans (1991), we use the term YD.

Cows were genotyped with different types of SNP chip, so imputation process was required to recover complete genotype information. For imputation, the whole genotyped French Holstein population (males (young and old) and females (with and without phenotypes) was used as a reference. Holstein males and females were genotyped with either Illumina BovineSNP50 Beadchip (50k, Illumina, San Diego, CA), or the customized EuroGenomics SNP chip (LD-chip, Amsterdam, the Netherlands). Two successive imputation steps were carried out. In the first step, 43,800 markers from the $50 \mathrm{k}$ were imputed, using all 50k genotypes as a reference. This step was carried out as part of the national evaluation procedure, before this study. In the second step carried out for the present study, additional functional variants were imputed, using animals genotyped for the functional variants included in the LD-chip as a reference. The LD-chip is composed of 2 parts: (1) 8,000 generic (and supposedly neutral) SNP mainly from BovineLD Genotyping BeadChip (Boichard et al., 2012a) and the 50k chip and (2) a custom part selected from wholegenome sequence variants based on different functional arguments: (1) known genetic variants described in literature, (2) potential regulatory variants located in the promoter regions of genes, (3) nonsynonymous variants with strongly deleterious effect on the function of the encoded protein as predicted by the variant effect predictor (McLaren et al., 2010), (4) breakpoints of structural variants affecting genes as described in Boussaha et al. (2015), and (5) variants corresponding to peaks in GWAS analysis of several economic traits in cattle. All SNP with minor allele frequency (MAF) lower than $0.5 \%$, with a call rate lower than $95 \%$, or deviating from Hardy-Weinberg proportions $\left(P<10^{-4}\right)$ were deleted. Four versions of this LD-chip were used, with partial overlap between custom parts. A total of 6,035 variants in LD-chip passed quality checks. Imputation was carried out using FImpute (Sargolzaei et al., 2014), for 187,025 genotyped Holstein animals (males and females, with or without performance records). Imputation errors may affect the 50k SNP not present on the LD-chip, and the candidate variants not present on the 50k. However, this consequence was likely small, as the loss in imputation error rate as expressed by allelic correlation was $<0.01$. After imputation, 49,835 SNP distributed over 29 BTA remained. 


\section{GWAS and QTL Detection}

Genome-wide association studies were performed with GCTA software (Yang et al., 2011). A mixed linear model association analysis was used to test associations between individual SNP and cows' MS, CM, and SCS. Because phenotypes were YD already adjusted for nongenetic effects, for each SNP $i$, the fitted model per trait was

$$
\mathbf{y}=1 \mu+\mathbf{x} \beta+\mathbf{g}+\varepsilon
$$

where $\mathbf{y}$ was the vector of YD for $\mathrm{n}$ cows, $\mu$ was a mean, $\beta$ was the allele substitution effect of SNP $i, \mathbf{x}$ was the vector of genotype dosages $(0,1$, or 2$)$ for SNP $i$, $\mathbf{g}$ was the vector of polygenic effect with $\mathbf{g} \sim N\left(\mathbf{0}, \mathbf{G} \sigma_{g}^{2}\right)$, and $\varepsilon$ was a vector of the residual effect with $\varepsilon \sim N\left(\mathbf{0}, \mathbf{I} \sigma_{\varepsilon}^{2}\right)$, where $\mathbf{I}$ was an $n \times n$ identity matrix. The variance of $\mathbf{y}$ was $\operatorname{var}(\mathbf{y})=\mathbf{G} \sigma_{g}^{2}+\mathbf{I} \sigma_{\varepsilon}^{2}$, where $\mathbf{G}$ was the genomic relationship matrix between cows, and $\sigma_{g}^{2}$ and $\sigma^{2}{ }_{e}$ were the genetic and residual variances. The relationship between cows $j$ and $k$ was

$$
g_{j k}=\frac{1}{w} \sum_{i=1}^{w} \frac{\left(z_{i j}-2 p_{i}\right)\left(z_{i k}-2 p_{i}\right)}{2 p_{i}\left(1-p_{i}\right)},
$$

where $w$ was the total number of SNP, $z_{i j}$ and $z_{i k}$ were the number of copies of the reference allele for the $i$ th SNP for the $j$ th and $k$ th cow, and $p_{i}$ was the frequency of the reference allele. To control the type I error rate, and assuming each test was independent, a Bonferroni genome-wide correction was applied. A genome-wide threshold was calculated as the ratio of the $\alpha$-level to total number of tests, that is, $P\left(T_{i} \mid H_{0}\right) \leq \frac{\alpha}{w}$, where $T_{i}$ is the test, $H_{0}$ is the null hypothesis, $\alpha=1 \%$, and $w=$ 49,835. In this study, $P=2.01 \times 10^{-7}$ or $-\log _{10} P=$ 6.70. A SNP was therefore considered significant if its $-\log _{10} P$ was greater than 6.70 .

The criteria for defining a QTL interval were as follows:

1. Select all SNP with a $-\log _{10} P$ equal to or exceeding the genome-wide threshold $-\log _{10} P \geq 6.70$.

2. For each selected SNP, define a $2-\mathrm{Mb}$ region (1 $\mathrm{Mb}$ on each side).

3. Within each $2-\mathrm{Mb}$ window, select the most significantly associated SNP as the lead SNP $(m)$ and $x=-\log _{10} P$.

4. Define a new threshold $(d)$ at LOD drop of 2 (in our case we used $-\log _{10} P$ drop of 2$)$, that is, $(d$ $=x-2)$ and select all SNP whose $-\log _{10} P \geq d$ inside the $2-\mathrm{Mb}$ region.

5. Discard $2 \mathrm{Mb}$ regions with $<4 \mathrm{SNP}$.

6. To determine the boundaries of the QTL regions, merge $2-\mathrm{Mb}$ regions using the following rules:

a. Calculate linkage disequilibrium (LD) between the lead SNP of window $i$ and the lead SNP of downstream regions using PLINK (Purcell et al., 2007).

b. A new region was defined from the starting point of interval $i$ to the endpoint of the nearest downstream region with $\mathrm{LD}>0.2$, and the lead SNP of the new regions (i.e., the SNP with the lowest $P$ ) was identified.

c. Repeat $\mathrm{a}$ and $\mathrm{b}$ until no LD higher than 0.2 exists between any pair of lead SNP on the chromosome and boundaries of QTL $i$ have been identified.

The procedure is repeated for region $i+1$ until the end of the chromosome has been reached, implying that QTL region will potentially be $>2 \mathrm{Mb}$ wide depending on LD and overlap.

For each QTL peak, the SNP with the highest $-\log _{10}$ $\mathrm{P}$ was identified as the lead SNP. The MS lead SNP per chromosome and MS QTL SNP for a QTL peak was tested for their association with CM and SCS with the same model described above for MS. The Bonferroni correction was applied by accounting for the number of tests on these traits (i.e., the number of SNP or the number of QTL significant for MS).

Information on significant SNP was obtained from the National Center for Biotechnology Information database of genetic variations (NCBI dbSNP Build 150; Sherry et al., 2001), functional annotation of genes from BioMart at the Ensembl Genome Browser 90 (Kinsella et al., 2011), Animal QTLdb (Hu et al., 2016), and gene ontology mined through Cytoscape (Shannon et al., 2003). The position of each SNP was defined according to the Bos taurus genome assembly UMD3.1 (Zimin et al., 2009).

\section{Heritability and Correlations}

Heritability coefficients were estimated for the 3 traits from both SNP and pedigree information. The SNP-based variances were calculated using GREML as implemented in the GCTA software, whereas pedigreebased variances were estimated by fitting a polygenic model as implemented in the Bayz software (Janss, 2014). In both instances, the model can be described as

$$
\mathbf{y}=1 \mu+\mathbf{a}+\mathbf{e}
$$


where $\mathbf{y}$ is the $(n \times 1)$ vector of $\mathrm{YD}$ and $\mathrm{n}=32,491$, $\mu$ is a common mean, $\mathbf{a}$ is a $(n \times 1)$ vector of additive genetic effects of the individuals, and $\mathbf{e}$ is a vector of random residuals. $\operatorname{Var}(\mathbf{a})$ was assumed to be proportional to the pedigree-based or SNP-based genetic relationship matrix, according to the model assumed.

Genetic correlations were obtained with Bayz in a 3 -trait model.

\section{RESULTS}

The SNP-based heritability estimate for 3 traits was $h_{M S}^{2}=0.37, h_{C M}^{2}=0.02$, and $h_{S C S}^{2}=0.38$. The pedigreebased heritability estimate for the 3 traits was $h_{M S}^{2}=$ $0.44, h_{C M}^{2}=0.04$, and $h_{S C S}^{2}=0.40$. For SCS, these high values are in the nature of $\mathrm{YD}$, which are means of repeated measures adjusted for permanent environmental effects (VanRaden and Wiggans, 1991). The pedigreebased genetic correlations were $r_{M S / C M}=0.16, r_{M S / S C S}=$ 0.47 , and $r_{C M / S C S}=0.75$.
The SNP array scans for MS revealed significantly associated markers in French Holstein cattle (Figure 1). A total of $971 \mathrm{SNP}$ on 22 chromosomes showed genome-wide significant associations with MS (Supplemental Table S1; https://doi.org/10.3168/jds.2017 -14067). The associated genomic regions and their lead SNP for MS for 22 chromosomes are presented in Table 1. The lead SNP for associated regions on BTA3, 5, 7, $8,9,14,16,17,18,20,22,26,28$, and 29 were located within genes and for BTA2, 10, 11, 12, 13, 19, 21, and 25 in intergenic regions. The top 3 strongest association signals were observed on BTA14 (rs110425867; $P$ $=1.77 \times 10^{-117} ; Z F A T$ gene $)$ BTA7 (rs41622861; $P$ $=1.07 \times 10^{-29} ;$ POLR2E gene), and BTA18 (Chr18: 57534701; $\left.P=2.19 \times 10^{-26}\right)$. The 5 most significant SNP on BTA18 were in the following positions (bp): $57,516,245$ (rs110801791), 57,516,702 (rs110572377), $57,517,094$ (rs109371542), 57,534,701 (rs381815997), and $57,536,322$ (rs378859840).

The most significant SNP per chromosome for CM is presented in Table 2. The 2 most significant SNP

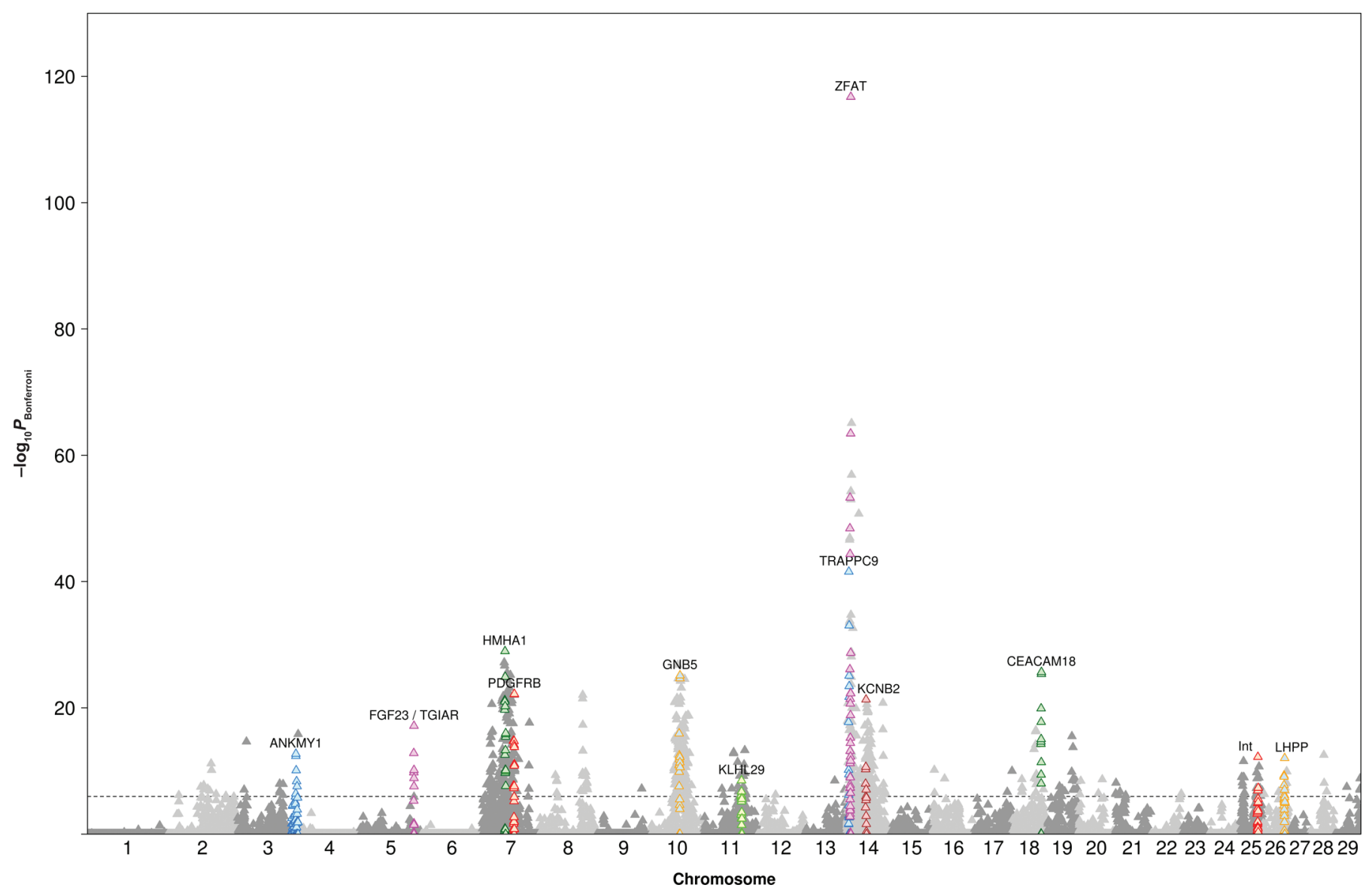

Figure 1. Manhattan plots of whole-genome association analysis for milking speed in French Holstein cattle. The x-axis represents chromosomes. The $\mathrm{y}$-axis represents Bonferroni-corrected $\log _{10}(P)$. Dotted line indicates genome-wide significance threshold at $P<2.01 \times 10^{-7}$, and different colors represent the QTL region. 


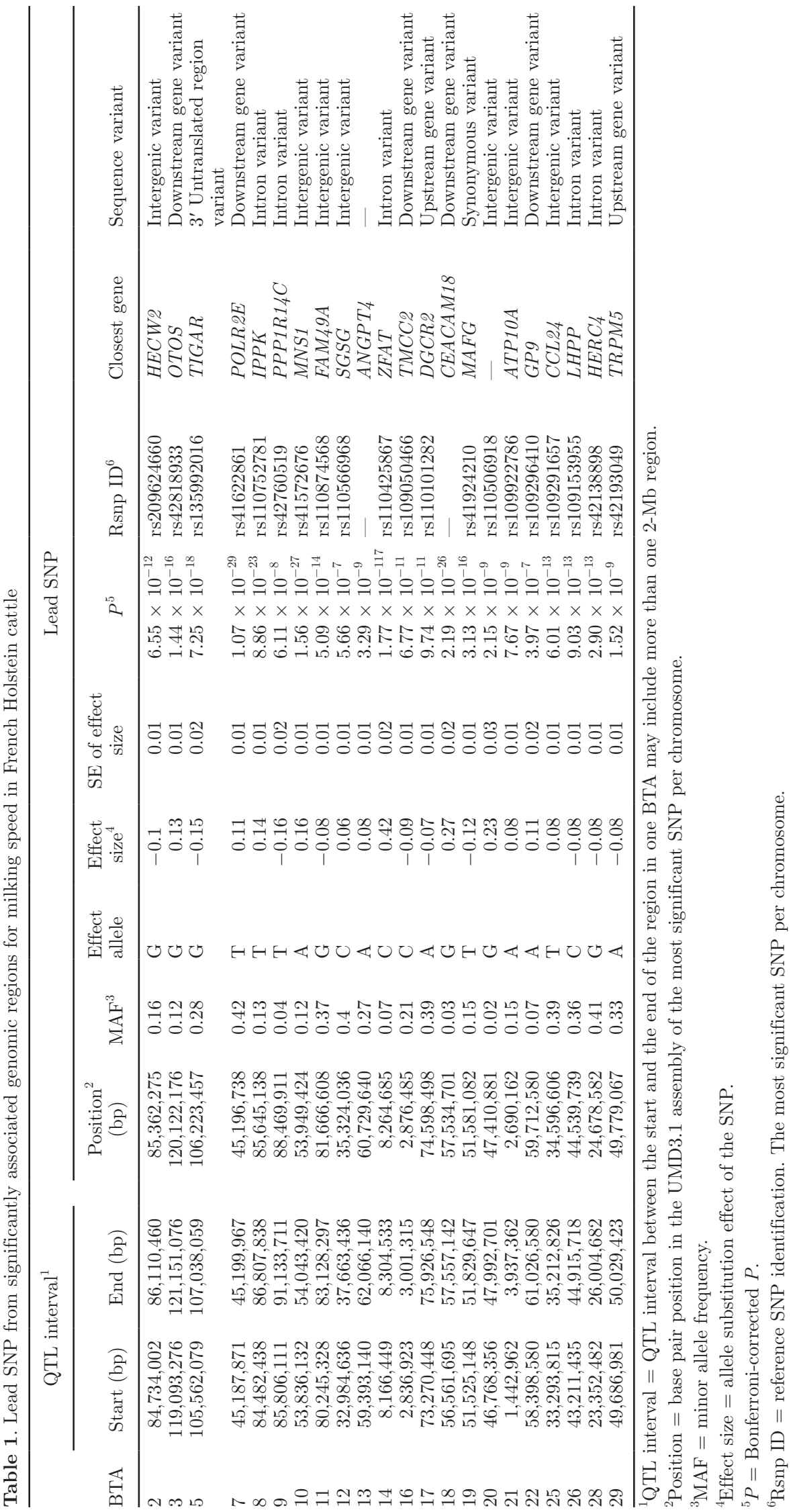


were on BTA11 (rs109293663; $P=3.44 \times 10^{-12}$; KLHL29 gene) and BTA8 (rs109145510; $P=1.08 \times$ $10^{-7}$; NUDT2 gene). The most significant SNP for SCS are presented in Table 3. Twenty-eight lead SNP were significant and 14 of these mapped within genes. The 3 most significant SNP were on BTA15 (rs42396627; $P=$ $1.03 \times 10^{-26}$; intergenic), BTA20 (rs29016097; $P=3.54$ $\times 10^{-20} ;$ HMGCS1 gene), and BTA16 (rs109540385; $P$ $=3.30 \times 10^{-18} ;$ ACOT7 gene). None of the lead SNP were lead SNP for more than one of the 3 traits. When we compared proximity of lead SNP with each other between 3 traits (Table 4), we observed 5 chromosomes where the lead SNP were located within $3 \mathrm{Mb}$ of each other. These were (1) MS/CM: BTA12 (1.02 Mb), BTA16 (2.26 Mb), BTA25 (2.18 Mb), and BTA29 (1 $\mathrm{Mb})$; and (2) MS/SCS: BTA25 (2.88 Mb). The allele substitution effects were generally low for all 3 traits for BTA 12 (MS: $\mathrm{b}=0.06 ; \mathrm{CM}: \mathrm{b}=-0.07)$, and BTA29 (MS: $\mathrm{b}=-0.08 ; \mathrm{CM}: \mathrm{b}=-0.05$; SCS: $\mathrm{b}=0.05)$. The genes where these lead SNP for SCS mapped included the TNFSF11 gene on BTA12 (rs109845266, $P=2.05$ $\left.\times 10^{-14}\right)$ and the ME3 gene BTA29 (rs384263462, $P=$ $\left.7.71 \times 10^{-7}\right)$.

Eleven novel MS QTL mapped by 483 significant SNP were observed on BTA7, 10, 11, 14, 18, 25, and 26 (Table 5). Ten QTL lead SNP mapped within genes, whereas one QTL lead SNP on BTA25 was in an intergenic region $>10 \mathrm{~kb}$ from nearest gene. Of the 10 lead SNP that mapped to a gene, rs110425867 on BTA14 was the most significant $\left[P=1.77 \times 10^{-117}\right.$, MAF $=$ 0.07 , effect size $=0.42(0.02), Z F A T$ gene]; the second was rs41622861 on BTA7 $\left[P=1.07 \times 10^{-29}\right.$, effect size $=0.11(0.01), \mathrm{MAF}=0.42, P O L R 2 E$ gene $]$; and the third was rs 42843551 on BTA18 $\left[P=2.19 \times 10^{-26}\right.$, effect size $=0.28(0.02), \mathrm{MAF}=0.03, C E A C A M 18$ gene $]$.

The 3 widest MS QTL intervals were on BTA7 (19,220,954, 6.3 Mb with 35 SNP), BTA7 (45,196,738, $4.9 \mathrm{Mb}$ with $37 \mathrm{SNP})$, and BTA7 (63,533,331, 4.6 Mb with 31 SNP).

The 3 smallest QTL intervals were on BTA14 (38,248,644, 1.5 Mb with 27 SNP), BTA18 $(57,534,701$, $1 \mathrm{Mb}$ with $13 \mathrm{SNP})$, and BTA10 (58,318,595, 0.4 Mb with 39 SNP; Figure 2). Two QTL lead SNP selected from imputed whole genome sequence variants in dairy cows mapped directly to gene: $P D G F R B$ and $C E A C A M 18$. Distribution per chromosome of the 11 QTL was such that BTA7 had 3 QTL; BTA10 had 1 QTL; BTA 11 had 1 QTL; BTA14 had 2 QTL; BTA18 had 1 QTL; BTA 25 had 2 QTL; and BTA26 had 1 QTL.

To check for pleiotropy between the MS QTL and significant SNP with SCS and CM, we compared significant GWAS SNP for MS for their effects on SCS and CM. First, we checked if the 971 genome-wide significant SNP associated with MS were also significant in CM and SCS. One hundred ninety-eight showed association with SCS, and 86 with CM (Figure 3). Second, we calculated the ratio of standardized allele substitution effects (i.e., allele substitution effect of the SNP divided by the genetic standard deviation of the trait) for the MS QTL lead SNP to SCS and CM. We compared the direction of this ratio to the genetic correlation of the traits. Because MS/SCS has a stronger genetic correlation $\left(\mathrm{r}_{\mathrm{MS} / \mathrm{SCS}}=0.47\right)$, we focused on ratios for these 2 traits. Of the 11 MS QTL, 4 had ratios not in line with the genetic correlation. These include QTL on BTA7, BTA10, and BTA25 (Table 6). In general, considering all QTL significant for MS, we observed limited pleiotropic effect of MS QTL SNP with CM or SCS (Figure 3).

\section{DISCUSSION}

Milking speed is here characterized by farmers' subjective appraisal of time taken to milk a cow on a scale of 1 (slow) to 5 (fast). The trait is recorded and routinely evaluated under the French cattle genetic evaluation system for type traits. Relatively high genomic (0.37) and pedigree heritability (0.44) estimates show that a subjective score based on repeated milking is very accurate under French conditions (i.e., with medium-sized herds). The genetic correlation between MS and $\mathrm{CM}$ was low (0.16), whereas the genetic correlation between MS and SCS was moderate (0.47) and high between CM and SCS (0.75). This is similar to those reported by Govignon-Gion et al. (2016) and Rupp and Boichard (1999) in the same population. Correlation between either MS and CM or MS and SCS is unfavorable as both instances increase the incidence of udder infection. Finding MS QTL whose SNP exhibit limited pleiotropic effects with CM and SCS could be beneficial to selecting for faster milking cows. An objective QTL selection logic is therefore paramount. In contrast to a study by Lipkin et al. (2016) that considered $P$-values only, our QTL selection logic accounted for both $P$ values and the long-range $\mathrm{LD}\left(\mathrm{r}^{2}\right)$ usually observed in dairy cattle. In our study, we report 11 MS QTL, of which 4 QTL are in limited pleiotropy with CM and SCS, suggesting that faster milking cows can be selected for, at least with QTL reported here, with only minimal risk of increases in SCS or CM.

Gene ontology (Shannon et al., 2003) on QTL SNP mapped several genes. Two interesting QTL were on BTA14 and mapped ZFAT gene, and KCNB2 gene: (1) ZFAT (zinc finger and AT-hook domain containing) is a protein that functions as an immune-related transcriptional regulator (Doi et al., 2011). It has been reported to promote fibroblast survival in model or- 


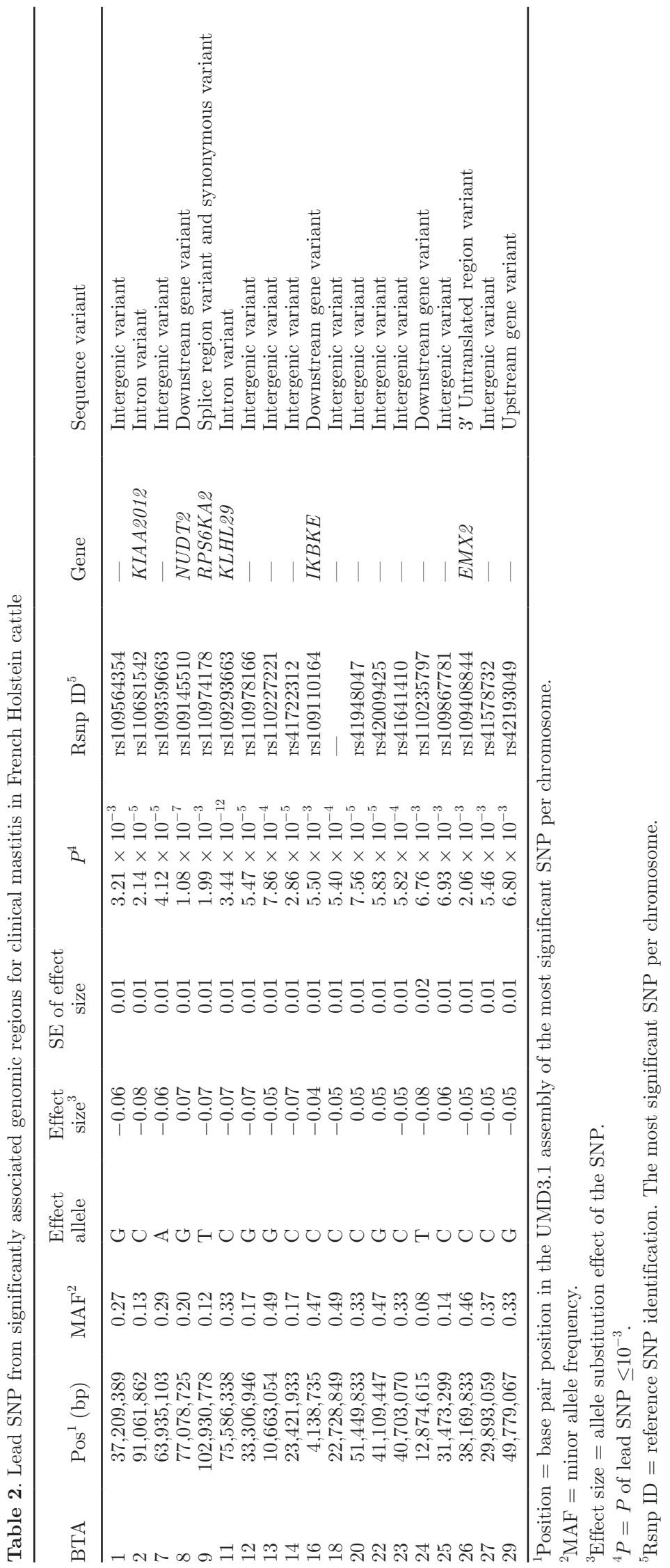


MARETE ET AL.

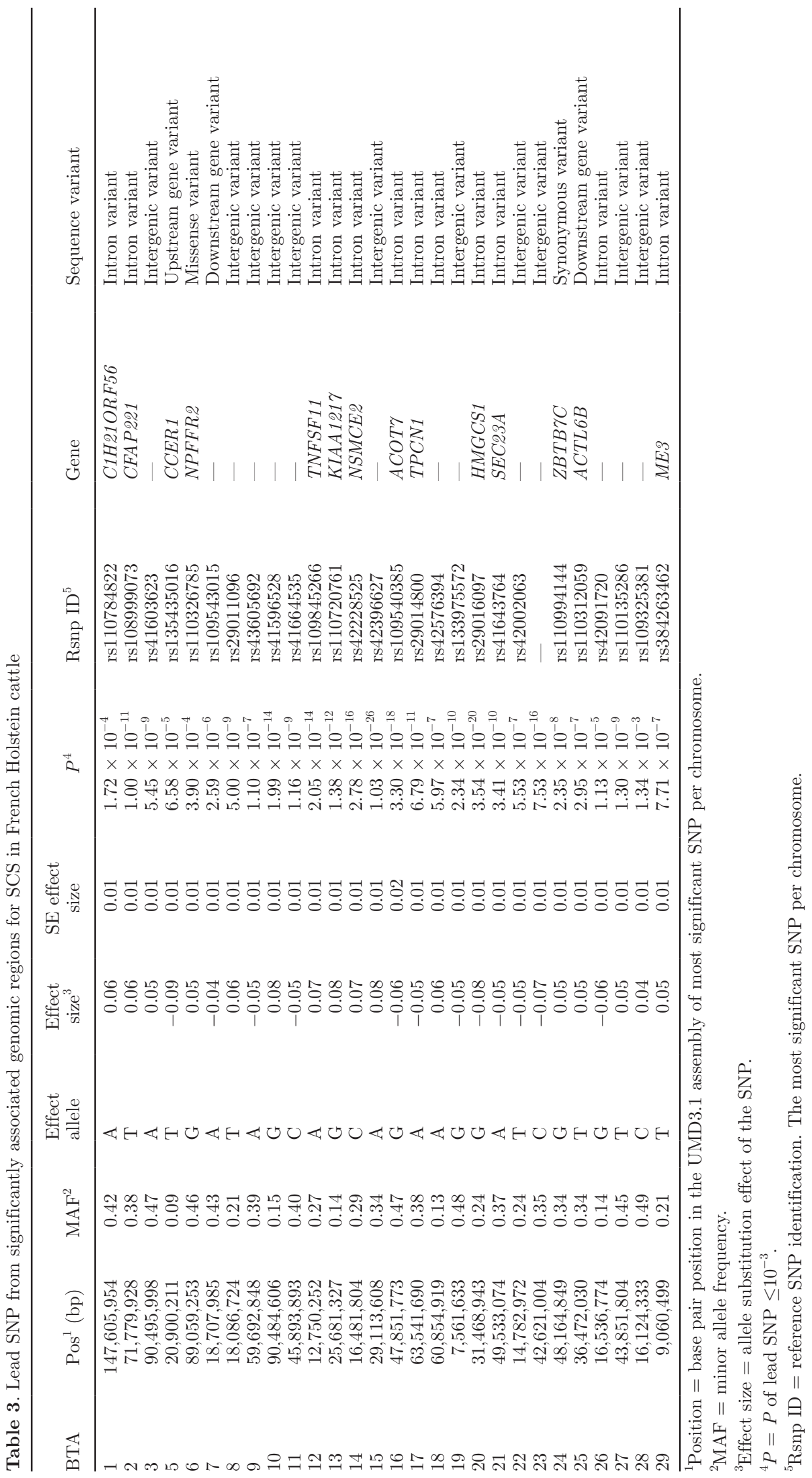


Table 4. Proximity of milking speed lead SNP position compared with clinical mastitis (CM) and SCS in French Holstein

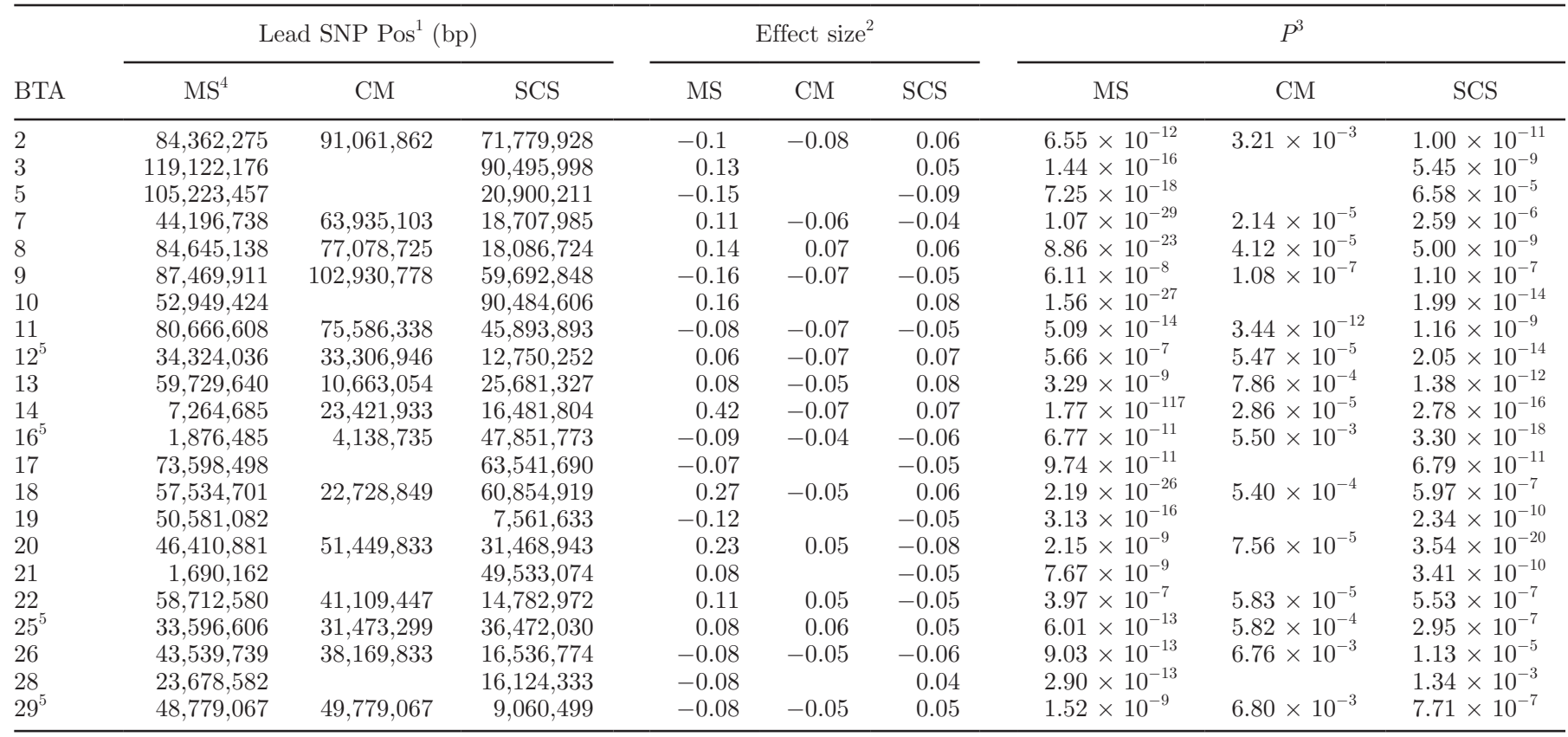

${ }^{1}$ Lead SNP $=$ most significant SNP per BTA. Pos (bp) = bp position in the UMD3.1 assembly.

${ }^{2}$ Effect size $=$ allele substitution effect; $\mathrm{SE} \leq 0.01$.

${ }^{3} P=P$ of lead $\mathrm{SNP} \leq 10^{-3}$.

${ }^{4} \mathrm{MS}=$ milking speed.

${ }^{5}$ Rows where the lead SNP are $<2.5 \mathrm{Mb}$ of each other.

ganisms (Koyanagi et al., 2008; Fujimoto et al., 2009). Fibroblasts are predominant components of mammary stroma (Darcy et al., 2000; Chen et al., 2016) and play crucial roles in the development and involution of the bovine mammary gland (Sladek and Rysanek, 2010). (2) KCNB2 (potassium voltage-gated channel subfamily B member 2) is a protein-coding gene. The protein is a member of a complex class of voltagegated ion channel that mediates transmembrane potassium transport in excitable membranes of smooth muscle (Vasan et al., 2007). Other QTL SNP mapped within several genes. These included QTL on BTA7: PLOR2E2 $[\mathrm{MAF}=0.4$, allele substitution effect $(\mathrm{b})=$ $0.11(0.01)$ ], PDGFRB [MAF $=0.29, \mathrm{~b}=0.11(0.01)$ ], QTL on BTA14: LRRC6 [MAF $=0.08, \mathrm{~b}=0.29(0.02)]$, and QTL on BTA18: CEACAM18 [MAF $=0.03, \mathrm{~b}=$ 0.28(0.02)]. The MAF for some of the SNP mapping to genes were low, and allele substitution effects were high. For instance, rs42843551 was a lead SNP in a QTL with 13 significant SNP within a 1-Mb region. Among its mapped genes include IL4I1 gene and CEACAM18 gene (carcinoembryonic antigen-related cell adhesion molecule). The CEACAM18 gene is of interest because it is a primordial member of the carcinoembryonic antigen family and reported to serve as a pathogen receptor in cattle (Kammerer et al., 2004), part of the immune system. The main immune system cell types are lymphocytes (Janeway et al., 2001). Several studies using model organisms and cattle data have shown that bovine peripheral blood lymphocytes express only immunoglobulin receptor family tyrosine-based inhibitory motifs containing CEACAM18 isoforms, and upregulate their expression upon stimulation, suggesting an inhibitory function in these cells (Donda et al., 2000; Markel et al., 2002). One such factor that plays a major role in regulating milk secretion in cattle (Wilde et al., 1997) and goats ( $\mathrm{Li}$ et al., 1999) is a feedback inhibitor of lactation found in milk. Feedback inhibitor of lactation is thought to be produced by the mammary cells as they synthesize and secrete milk (Wilde et al., 1997; Janeway et al., 2001). Accumulation of feedback inhibitor of lactation in the milk-producing alveoli results in feedback inhibition of milk synthesis and secretion (Wilde et al., 1990), thus increasing the time taken to milk a cow. The IL $4 I 1$ gene (interleukin 4 induced 1) on BTA18: 56,691,667-56,725,849 is a protein-coding gene whose related pathways include tyrosine metabolism. Tyrosine regulates mammary epithelial cell proliferation by activating the AKT serine/threonine kinase 1 (AKT1) gene at the transcriptional level in mammary glands of dairy cows (Crompton et al., 2014; Hou et al., 2016). The ATK1 gene is important for the mam- 


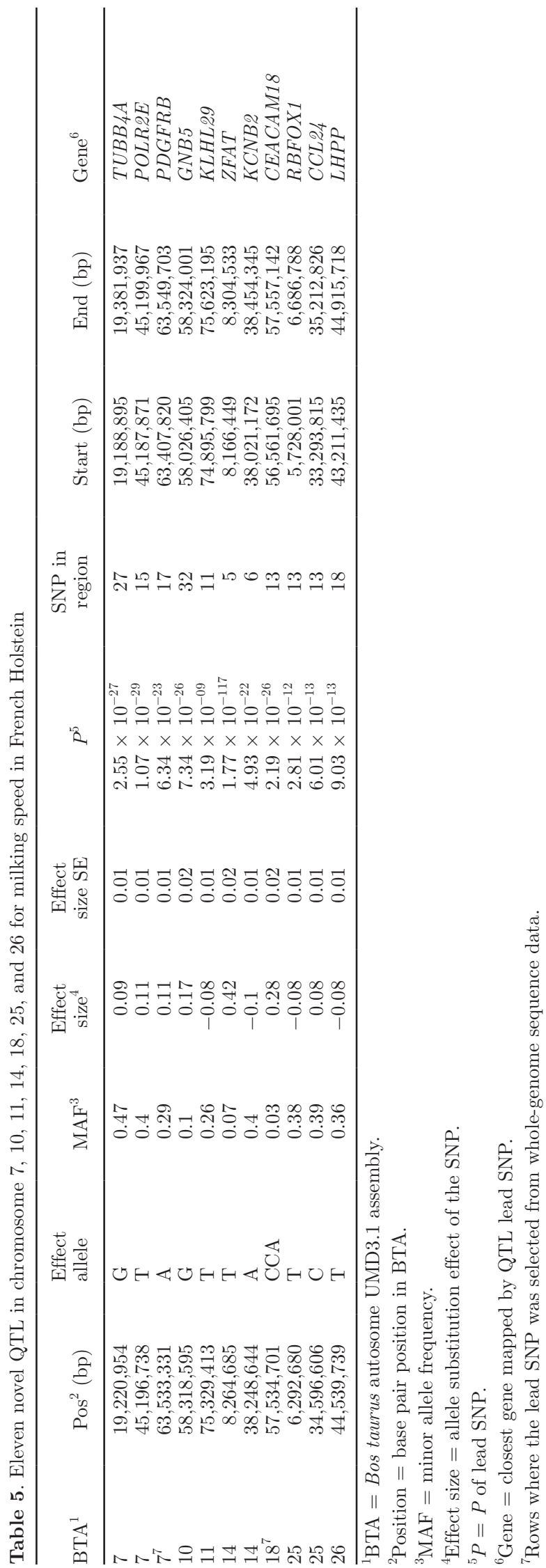

mary remodeling process in dry cows as well as for increasing persistency of lactation in lactating cows (Hou et al., 2016).

General GWAS results as presented in Figure 1 and Table 1 show clear peaks on BTA5 (TIGAR gene), BTA8 (IPPK gene), and BTA10 (MNS1 gene). Similarly, Jardim et al. (2018) reported QTL for MS on several chromosomes including BTA5, BTA8, and BTA10. These QTL overlapped with the significantly associated regions identified in our study. The TP53 induced glycolysis regulatory phosphatase $(T I G A R)$ is a p53-regulated gene. The p53 is a stress-induced transcription factor that controls various cellular response mechanisms including cell cycle arrest and apoptosis ( $\mathrm{Li}$ and Jogl, 2009). Its expression can influence the release of oxytocin response during pregnancy and lactation in model organisms (Soloff and Wieder, 1983) and oxytocin is released in cows for the letdown of milk (Watters et al., 2015). The timing of oxytocin release relative to milk removal is an important factor affecting milk ejection and persistency during lactation (Nostrand et al., 1991). POLR2E and IPPK are protein-coding genes. They are associated with the canonical pathway glucocorticoid receptor signaling. This is of interest because glucocorticoid receptor signaling exerts antiinflammatory effects on mammary cells during injury, as would be caused by a bacterial infection (Smoak and Cidlowski, 2004). Based on all these known functions, these genes can be considered as functional candidate genes.

Furthermore, lead SNP among MS, CM, and SCS were different (Table 4). The allele substitution effects were similar for the 2 lead SNP: TNFSF11 gene on BTA12 (rs109845266) and ME3 gene on BTA29 (rs384263462). The TNFSF11 is a protein-coding gene with main gene ontology biological functions including calcium ion homeostasis, mammary gland alveolus development, bone resorption, calcium-mediated signaling, and immune response (Yates et al., 2016). The ME3 gene is a malic enzyme involved in pyruvate metabolism. Previous studies have shown that pyruvate accumulation caused by inhibition of lipid metabolism can cause hypoxia signaling in mastitis in cattle (Genini et al., 2011). The TNFSF11 had positive substitution effects for SCS and MS, whereas ME3 had a positive substitution effect for SCS only.

\section{CONCLUSIONS}

Increased MS is of economic interest in cows because milking is a major component of the workload of the farmer. But increased MS should be obtained without deteriorating mastitis resistance, or even better while improving mastitis resistance. In the French Holstein, 

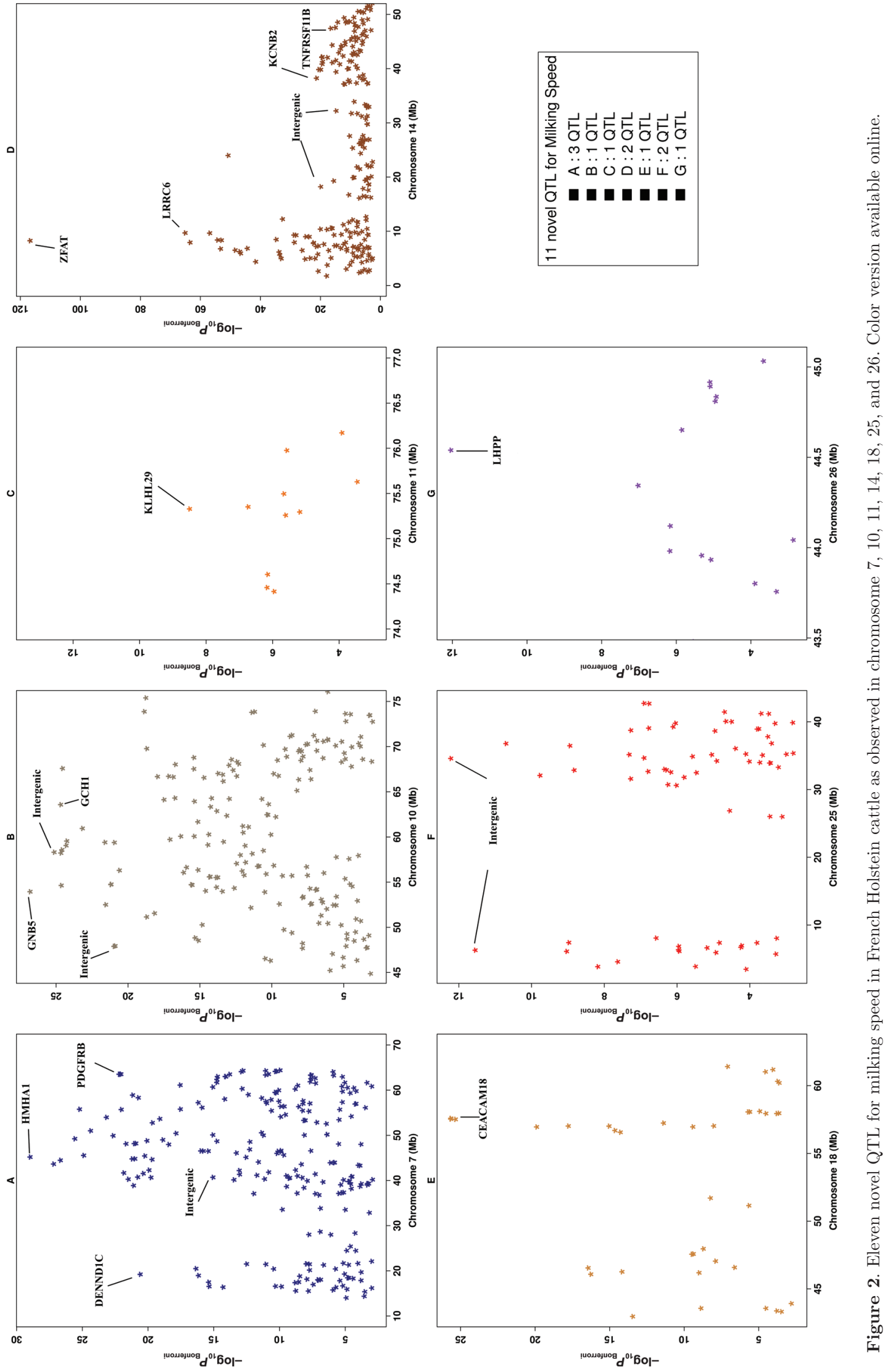

Journal of Dairy Science Vol. 101 No. 7, 2018 
MS accounts for $5 \%$ of the total merit index, whereas udder health (SCS and CM) accounts for $18 \%$. The GWAS SNP from whole genome sequence variants as incorporated in the EuroGenomics chip and 50k SNP data identified several variants that likely influence MS in French Holstein cattle. We identified several candi- date genes for MS including HMHA1, POLR2E, GNB5, KLHL29, ZFAT, KCNB2, CEACAM18, CCL24, LHPP, PDGFRB, TIGAR, and IL4II. We also identified 11 MS QTL, of which 4 may allow for selecting for increased MS without increased incidence of CM. Finding quantitative trait nucleotides is challenging, as there
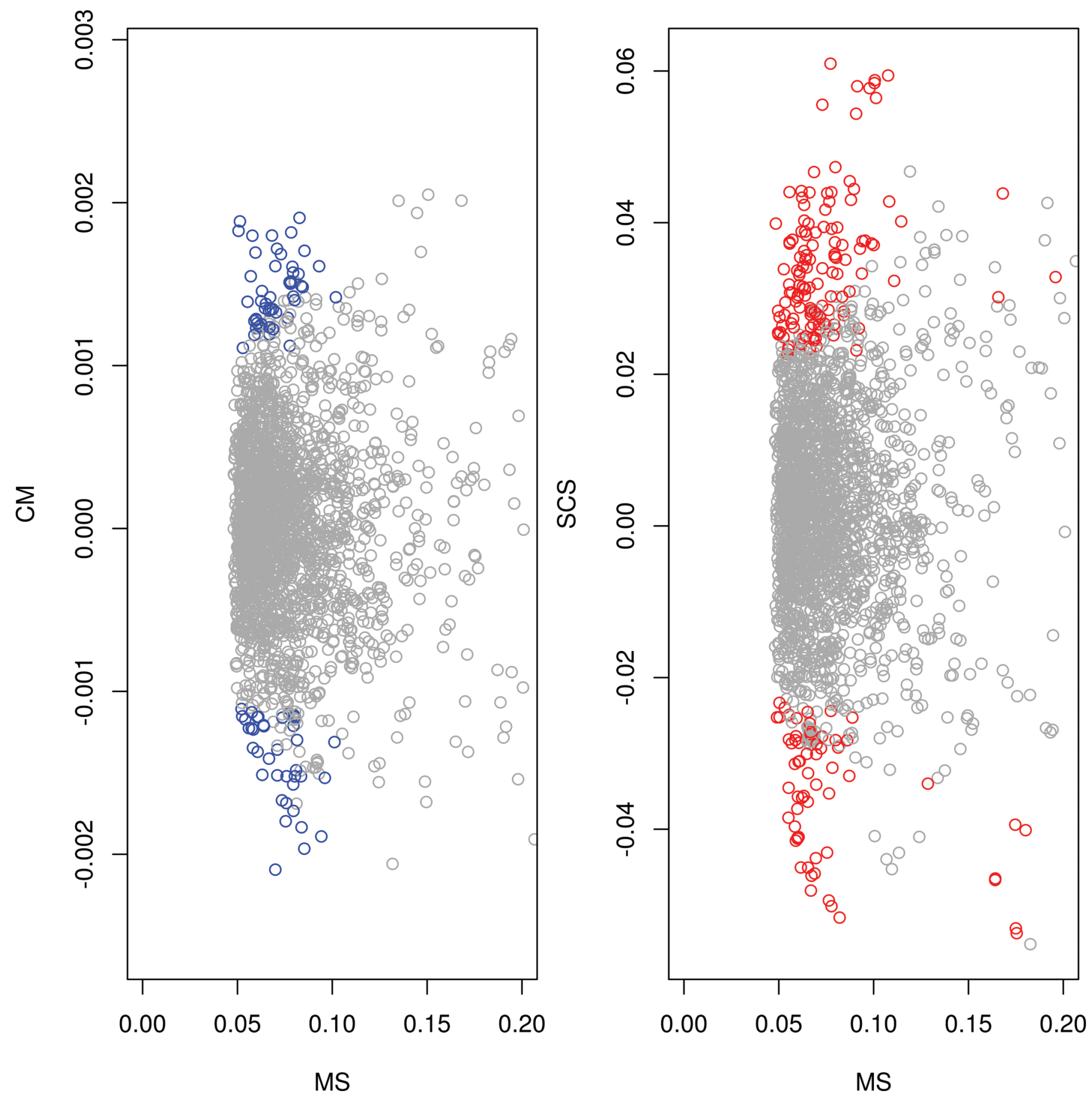

Figure 3. The plot of standardized allele substitution effects for significant genome-wide association study SNP associated with milking speed (MS), clinical mastitis (CM), and SCS. Left indicates a change in CM; right indicates a change in SCS. Color version available online. 


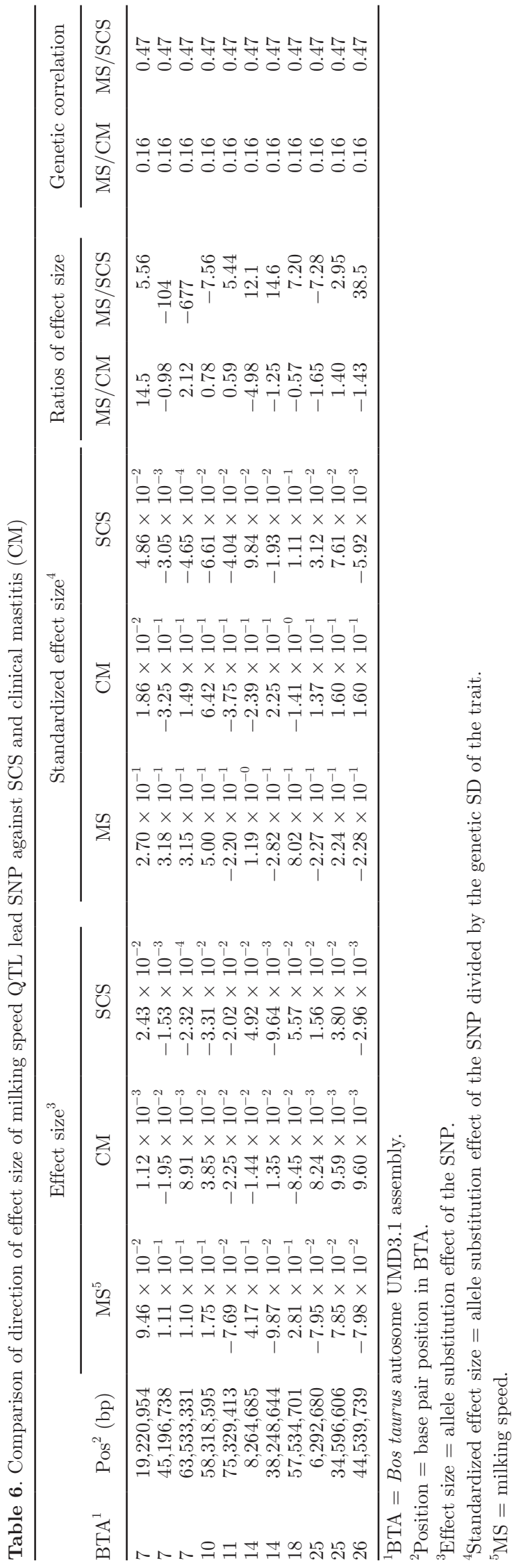

are many regions of LD and small-effect QTL. The QTL reported on this study can be used to augment the dairy cattle QTL database for better prediction accuracy in routine genomic selection. Further study is needed to find an optimum MS to avoid any negative effect on mastitis incidence.

\section{ACKNOWLEDGMENTS}

The authors are grateful to the French National Animal Breeding Database for providing phenotypic data, Valogene for cows' genotypes, and INRA for providing the study environment. Andrew Marete is the recipient of an Erasmus Mundus $\mathrm{PhD}$ grant funded jointly by the European Graduate School in Animal Breeding and Genetics, Viking Genetics (Denmark), and Center for Genomic Selection in Animals and Plants (GenSAP) funded by Innovation Fund Denmark (grant 060300519B). The authors declare no competing interest. DB and MSL conceived and designed the study. AGM analyzed the data and wrote the manuscript. GS, BG, $\mathrm{RL}, \mathrm{AB}$, and $\mathrm{SF}$ contributed materials and analysis tools and participated in the discussion. All authors read, revised, and approved the final manuscript.

\section{REFERENCES}

Boettcher, P. J. J., J. C. M. C. Dekkers, and B. W. W. Kolstad. 1998. Development of an udder health index for sire selection based on somatic cell score, udder conformation, and milking speed. J. Dairy Sci. 81:1157-1168. https://doi.org/10.3168/jds.S0022 -0302(98)75678-4.

Boichard, D., H. Chung, R. Dassonneville, X. David, A. A. Eggen, S. S. Fritz, K. J. Gietzen, B. J. Hayes, C. T. Lawley, T. S. Sonstegard, C. P. van Tassell, P. M. VanRaden, K. A. Viaud-Martinez, and G. R. Wiggans. 2012a. Design of a bovine low-density SNP array optimized for imputation. PLoS One 7:e34130. https://doi .org/10.1371/journal.pone.0034130.

Boichard, D., F. Guillaume, A. Baur, P. Croiseau, M. N. Rossignol, M. Y. Boscher, T. Druet, L. Genestout, J. J. Colleau, L. Journaux, V. Ducrocq, and S. Fritz. 2012b. Genomic selection in French dairy cattle. Anim. Prod. Sci. 52:115-120. https://doi.org/10.1071/ AN11119.

Boussaha, M., D. Esquerré, J. Barbieri, A. Djari, A. Pinton, R. Letaief, G. Salin, F. Escudié, A. Roulet, S. Fritz, F. Samson, C. Grohs, M. Bernard, C. Klopp, D. Boichard, and D. Rocha. 2015. Genomewide study of structural variants in bovine Holstein, Montbeliarde and Normande dairy breeds. PLoS One 10:e0135931. https://doi .org/10.1371/journal.pone.0135931.

Chen, Q., G. He, W. Zhang, T. Xu, H. Qi, J. Li, Y. Zhang, M.-Q. Gao, X. Zhao, P. Lacasse, O. Wellnitz, R. M. Bruckmaier, M. Rinaldi, E. E. Connor, K. Polyak, R. Kalluri, K. M. Darcy, T. Casey, R. S. Smith, T. J. Smith, T. M. Blieden, R. P. Phipps, C. D. Buckley, M. Jordana, B. Sarnstrand, P. J. Sime, I. Ramis, L. K. T. De, C. V. Whiting, P. W. Bland, H. Kitamura, N. Erez, M. Truitt, P. Olson, S. T. Arron, D. Hanahan, Z. Sladek, D. Rysanek, H. Ryznarova, M. Faldyna, Z. Sladek, D. Rysanek, Z. Sladek, H. Ryznarova, D. Rysanek, L. M. Sordillo, K. L. Streicher, C. Riollet, P. Rainard, B. Poutrel, C. D. Buckley, D. Pohlers, S. J. Flavell, D. D. Bannerman, Y. H. Schukken, J. Oviedo-Boyso, N. Landolina, R. S. Gangwar, F. Levi-Schaffer, S. Van Linthout, K. Miteva, C. Tschope, T. Oda, R. Patel, A. Filer, F. Barone, C. D. Buckley, M. Loeffler, J. A. Kruger, A. G. Niethammer, R. A. Reisfeld, H. Lahouassa, 
E. Moussay, P. Rainard, C. Riollet, O. Maller, H. Martinson, P. Schedin, T. Katsuta, M. Q. Gao, C. H. Da, G. Ge, P. Xiao, Y. Zhang, L. Yang, X. Wang, J. Ye, and M. Kanehisa. 2016. Stromal fibroblasts derived from mammary gland of bovine with mastitis display inflammation-specific changes. Sci. Rep. 6:27462. https:// doi.org/10.1038/srep27462.

Crompton, L. A., J. France, C. K. Reynolds, J. A. N. Mills, M. D. Hanigan, J. L. Ellis, A. Bannink, B. J. Bequette, and J. Dijkstra. 2014. An isotope dilution model for partitioning phenylalanine and tyrosine uptake by the mammary gland of lactating dairy cows. J. Theor. Biol. 359:54-60. https://doi.org/10.1016/j.jtbi.2014.05.012.

Darcy, K. M., D. Zangani, W. Shea-Eaton, S. F. Shoemaker, P. P. Lee, L. H. Mead, A. Mudipalli, R. Megan, and M. M. Ip. 2000. Mammary fibroblasts stimulate growth, alveolar morphogenesis, and functional differentiation of normal rat mammary epithelial cells. In Vitro Cell. Dev. Biol. Anim. 36:578-592. https://doi.org/ $10.1007 / \mathrm{BF} 02577526$.

Davis, K. L., W. J. Fulkerson, S. C. Garcia, D. Dickeson, and I. M. Barchia. 2008. Premilking teat preparation for Australian pasturebased cows milked by an automated milking system. J. Dairy Sci. 91:2604-2609. https://doi.org/10.3168/jds.2007-0641.

Dodd, F. H., and F. K. Neave. 1951. 448. Machine milking rate and mastitis. J. Dairy Res. 18:240-245. https://doi.org/10.1017/ S0022029900006117.

Doi, K., T. Fujimoto, M. Koyanagi, T. Tsunoda, Y. Tanaka, Y. Yoshida, Y. Takashima, M. Kuroki, T. Sasazuki, and S. Shirasawa. 2011. ZFAT is a critical molecule for cell survival in mouse embryonic fibroblasts. Cell. Mol. Biol. Lett. 16:89-100. https://doi.org/ 10.2478/s11658-010-0041-1.

Donda, A., L. Mori, A. Shamshiev, I. Carena, C. Mottet, M. H. Heim, C. Beglinger, F. Grunert, C. Rochlitz, L. Terracciano, P. Jantscheff, and G. De Libero. 2000. Locally inducible CD66a (CEACAM1) as an amplifier of the human intestinal T cell response. Eur. J. Immunol. 30:2593-2603. https://doi.org/10.1002/1521-4141(200009)30: $9<2593::$ AID-IMMU2593>3.0.CO;2-0.

Ferneborg, S., and K. Svennersten-Sjaunja. 2015. The effect of pulsation ratio on teat condition, milk somatic cell count and productivity in dairy cows in automatic milking. J. Dairy Res. 82:453-459. https://doi.org/10.1017/S0022029915000515.

Fujimoto, T., K. Doi, M. Koyanagi, T. Tsunoda, Y. Takashima, Y. Yoshida, T. Sasazuki, and S. Shirasawa. 2009. ZFAT is an antiapoptotic molecule and critical for cell survival in MOLT-4 cells. FEBS Lett. 583:568-572. https://doi.org/10.1016/j.febslet.2008.12.063.

Gäde, S., E. Stamer, J. Bennewitz, W. Junge, and E. Kalm. 2007. Genetic parameters for serial, automatically recorded milkability and its relationship to udder health in dairy cattle. Animal 1:787-796. https://doi.org/10.1017/S1751731107000092.

Genini, S., B. Badaoui, G. Sclep, S. C. Bishop, D. Waddington, M.-H Pinard van der Laan, C. Klopp, C. Cabau, H.-M. Seyfert, W. Petzl, K. Jensen, E. J. Glass, A. de Greeff, H. E. Smith, M. A. Smits, I. Olsaker, G. M. Boman, G. Pisoni, P. Moroni, B. Castiglioni, P. Cremonesi, M. Del Corvo, E. Foulon, G. Foucras, R. Rupp, and E. Giuffra. 2011. Strengthening insights into host responses to mastitis infection in ruminants by combining heterogeneous microarray data sources. BMC Genomics 12:225. https://doi.org/10.1186/ 1471-2164-12-225.

Govignon-Gion, A., R. Dassonneville, G. Baloche, and V. Ducrocq. 2016. Multiple trait genetic evaluation of clinical mastitis in three dairy cattle breeds. Animal 10:558-565. https://doi.org/10.1017/ S1751731115002529.

Hoefelmayr, T., and W. M. B. A. G. Faerber. Balgach, Switzerland 2007. The LactoCorder ${ }^{\circledR}$ Mobile Milk Flowmeter in Milk Recording and Consulting. ART-Schriftenreihe, Balgach, Switzerland.

Hou, X., L. Lin, W. Xing, Y. Yang, X. Duan, Q. Li, X. Gao, and Y. Lin. 2016. Spleen tyrosine kinase regulates mammary epithelial cell proliferation in mammary glands of dairy cows. J. Dairy Sci. 99:3858-3868. https://doi.org/10.3168/jds.2015-10118.

Hu, Z. L., C. A. Park, and J. M. Reecy. 2016. Developmental progress and current status of the Animal QTLdb. Nucleic Acids Res. 44:D827-D833. https://doi.org/10.1093/nar/gkv1233.
Janeway, C. A., Jr., P. Travers, and M. Walport. 2001. Principles of innate and adaptive immunity. Immunobiology: The Immune System in Health and Disease. 5th ed. Garland Science, New York, NY.

Janss, L. L. G. 2014. BayZ manual version 2.2. http://www.bayz.biz/ Janss Biostatistics, Leiden, the Netherlands.

Jardim, J. G., B. Guldbrandtsen, M. S. Lund, and G. Sahana. 2018. Association analysis for udder index and milking speed with imputed whole-genome sequence variants in Nordic Holstein cattle. J. Dairy Sci. 101:2199-2212. https://doi.org/10.3168/jds.2017-12982.

Kammerer, R., T. Popp, B. B. Singer, J. Schlender, and W. Zimmermann. 2004. Identification of allelic variants of the bovine immune regulatory molecule CEACAM1 implies a pathogen-driven evolution. Gene 339:99-109. https://doi.org/10.1016/j.gene.2004 .06 .023 .

Kinsella, R. J., A. Kähäri, S. Haider, J. Zamora, G. Proctor, G. Spudich, J. Almeida-King, D. Staines, P. Derwent, A. Kerhornou, P Kersey, and P. Flicek. 2011. Ensembl BioMarts: A hub for data retrieval across taxonomic space. Database 2011:bar030. https:// doi.org/10.1093/database/bar030.

Koyanagi, M., K. Nakabayashi, T. Fujimoto, N. Gu, I. Baba, Y. Takashima, K. Doi, H. Harada, N. Kato, T. Sasazuki, and S. Shirasawa. 2008. ZFAT expression in B and T lymphocytes and identification of ZFAT-regulated genes. Genomics 91:451-457. https:// doi.org/10.1016/j.ygeno.2008.01.009.

Li, H., and G. Jogl. 2009. Structural and biochemical studies of TIGAR (TP53-induced glycolysis and apoptosis regulator). J. Biol. Chem. 284:1748-1754. https://doi.org/10.1074/jbc.M807821200.

Li, P., C. J. Wilde, L. M. B. Finch, D. G. Fernig, and P. S. Rudland. 1999. Identification of cell types in the developing goat mammary gland. Histochem. J. 31:379-393. https://doi.org/10.1023/A: 1003700224900

Lipkin, E., M. G. Strillacci, H. Eitam, M. Yishay, F. Schiavini, M. Soller, A. Bagnato, and A. Shabtay. 2016. The use of Kosher phenotyping for mapping QTL affecting susceptibility to bovine respiratory disease. PLoS One 11:e0153423. https://doi.org/10.1371/ journal.pone.0153423.

Markel, G., N. Lieberman, G. Katz, T. I. Arnon, M. Lotem, O. Drize, R. S. Blumberg, E. Bar-Haim, R. Mader, L. Eisenbach, and O. Mandelboim. 2002. CD66a interactions between human melanoma and NK Cells: A novel class I MHC-independent inhibitory mechanism of cytotoxicity. J. Immunol. 168:2803-2810. https://doi.org/ 10.4049/jimmunol.168.6.2803.

McLaren, W., B. Pritchard, D. Rios, Y. Chen, P. Flicek, and F. Cunningham. 2010. Deriving the consequences of genomic variants with the Ensembl API and SNP effect predictor. Bioinformatics 26:2069-2070. https://doi.org/10.1093/bioinformatics/btq330.

Nostrand, S. D., D. M. Galton, H. N. Erb, and D. E. Bauman. 1991. Effects of daily exogenous oxytocin on lactation milk yield and composition. J. Dairy Sci. 74:2119-2127. https://doi.org/10.3168/ jds.S0022-0302(91)78384-7.

Purcell, S., B. Neale, K. Todd-Brown, L. Thomas, M. A. R. Ferreira D. Bender, J. Maller, P. Sklar, P. I. W. De Bakker, M. J. Daly, and P. C. Sham. 2007. REPORT PLINK: A tool set for whole-genome association and population-based linkage analyses. Am. J. Hum. Genet. 81:559-575. https://doi.org/10.1086/519795.

Rupp, R., and D. Boichard. 1999. Genetic parameters for clinical mastitis, somatic cell score, production, udder type traits, and milking ease in first lactation Holsteins. J. Dairy Sci. 82:2198-2204. https://doi.org/10.3168/jds.S0022-0302(99)75465-2.

Samoré, A. B., R. Rizzi, A. Rossoni, and A. Bagnato. 2010. Genetic parameters for functional longevity, type traits, somatic cell scores, milk flow and production in the Italian Brown Swiss. Ital. J. Anim. Sci. 9:e28. https://doi.org/10.4081/ijas.2010.e28.

Sargolzaei, M., J. P. Chesnais, and F. S. Schenkel. 2014. A new approach for efficient genotype imputation using information from relatives. BMC Genomics 15:478. https://doi.org/10.1186/1471 $-2164-15-478$.

Sewalem, A., F. Miglior, and G. J. Kistemaker. 2011. Genetic parameters of milking temperament and milking speed in Canadian 
Holsteins. J. Dairy Sci. 94:512-516. https://doi.org/10.3168/jds .2010-3479.

Shannon, P., A. Markiel, O. Ozier, N. S. Baliga, J. T. Wang, D. Ramage, N. Amin, B. Schwikowski, and T. Ideker. 2003. Cytoscape: A software environment for integrated models of biomolecular interaction networks. Genome Res. 13:2498-2504. https://doi.org/10 $.1101 /$ gr. 1239303 .

Sherry, S. T., M. H. Ward, M. Kholodov, J. Baker, L. Phan, E. M. Smigielski, and K. Sirotkin. 2001. dbSNP: The NCBI database of genetic variation. Nucleic Acids Res. 29:308-311. https://doi.org/ 10.1093/nar/29.1.308.

Sladek, Z., and D. Rysanek. 2010. Apoptosis of resident and inflammatory macrophages before and during the inflammatory response of the virgin bovine mammary gland. Acta Vet. Scand. 52:12. https://doi.org/10.1186/1751-0147-52-12.

Smoak, K. A., and J. A. Cidlowski. 2004. Mechanisms of glucocorticoid receptor signaling during inflammation. Mech. Ageing Dev. 125:697-706. https://doi.org/10.1016/j.mad.2004.06.010.

Soloff, M. S., and M. H. Wieder. 1983. Oxytocin receptors in rat involuting mammary gland. Can. J. Biochem. Cell Biol. 61:631-635. https://doi.org/10.1139/o83-079.

VanRaden, P. M., and G. R. Wiggans. 1991. Derivation, calculation and use of national animal model information. J. Dairy Sci. 74:2737-2746. https://doi.org/10.3168/jds.S0022-0302(91)78453 -1 .

Vasan, R. S., M. G. Larson, J. Aragam, T. J. Wang, G. F. Mitchell, S. Kathiresan, C. Newton-Cheh, J. A. Vita, M. J. Keyes, C. J. O'Donnell, D. Levy, and E. J. Benjamin. 2007. Genome-wide association of echocardiographic dimensions, brachial artery endothelial function and treadmill exercise responses in the Framingham Heart Study. BMC Med. Genet. 8:S2. https://doi.org/10.1186/ 1471-2350-8-S1-S2.

Watters, R. D., R. M. Bruckmaier, H. M. Crawford, N. Schuring, Y. H. Schukken, and D. M. Galton. 2015. The effect of manual and mechanical stimulation on oxytocin release and milking char- acteristics in Holstein cows milked 3 times daily. J. Dairy Sci. 98:1721-1729. https://doi.org/10.3168/jds.2014-8335.

Wiggans, G. R., L. L. M. Thornton, R. R. Neitzel, and N. Gengler. 2007. Short communication: Genetic evaluation of milking speed for Brown Swiss dairy cattle in the United States. J. Dairy Sci. 90:1021-1023. https://doi.org/10.3168/jds.S0022-0302(07)71587 -4 .

Wilde, C. J., C. V. Addey, P. Li, and D. G. Fernig. 1997. Programmed cell death in bovine mammary tissue during lactation and involution. Exp. Physiol. 82:943-953. https://doi.org/10.1113/ expphysiol.1997.sp004075.

Wilde, C. J., C. H. Knight, C. V. P. Addey, D. R. Blatchford, M. Travers, C. N. Bennett, and M. Peaker. 1990. Autocrine regulation of mammary cell differentiation. Protoplasma 159:112-117. https:// doi.org/10.1007/BF01322594.

Yang, J., S. H. Lee, M. E. Goddard, and P. M. Visscher. 2011. GCTA: A tool for genome-wide complex trait analysis. Am. J. Hum. Genet. 88:76-82. https://doi.org/10.1016/j.ajhg.2010.11.011.

Yates, A., W. Akanni, M. R. Amode, D. Barrell, K. Billis, D. Carvalho-Silva, C. Cummins, P. Clapham, S. Fitzgerald, L. Gil, C. G. Girón, L. Gordon, T. Hourlier, S. E. Hunt, S. H. Janacek, N. Johnson, T. Juettemann, S. Keenan, I. Lavidas, F. J. Martin, T. Maurel, W. McLaren, D. N. Murphy, R. Nag, M. Nuhn, A. Parker, M. Patricio, M. Pignatelli, M. Rahtz, H. S. Riat, D. Sheppard, K. Taylor, A. Thormann, A. Vullo, S. P. Wilder, A. Zadissa, E. Birney, J. Harrow, M. Muffato, E. Perry, M. Ruffier, G. Spudich, S. J. Trevanion, F. Cunningham, B. L. Aken, D. R. Zerbino, and P. Flicek. 2016. Ensembl 2016. Nucleic Acids Res. 44:D710-D716. https://doi.org/10.1093/nar/gkv1157.

Zimin, A. V., A. L. Delcher, L. Florea, D. R. Kelley, M. C. Schatz, D. Puiu, F. Hanrahan, G. Pertea, C. P. Van Tassell, T. S. Sonstegard, G. Marçais, M. Roberts, P. Subramanian, J. A. Yorke, and S. L. Salzberg. 2009. A whole-genome assembly of the domestic cow, Bos taurus. Genome Biol. 10:R42. https://doi.org/10.1186/ gb-2009-10-4-r42. 